\title{
Bertold Brecht: comunicação, poesia e revolução
}

Adilson Citelli

Professor livre-docente no Departamento de Comunicações e Artes da ECA-USP

e chefe do Departamento de Comunicações e Artes.

E-mail: citelli@uol.com.br

Nos dois últimos números da Comunicação \& Educação', dedicamo-nos a mostrar como se desdobram nos textos poéticos determinados processos de apropriação intertextuais e interdiscursivos. Falamos, então, das recorrências entre Eduardo Alves da Costa, Martin Niemöller e Bertold Brecht. Acerca dos dois primeiros, fizemos comentários e arrolamos textos; sobre o último, reservamos esta edição da revista.

Eugen Berthold Friedrich Brecht (Bertold Brecht) nasceu na cidade alemã de Augsburg, na Baviera, em 10 de fevereiro de 1898, e morreu em 14 de agosto de 1956, em Berlim. Dramaturgo, poeta, teórico do teatro, agitador de idéias, Brecht é considerado um dos mais importantes teatrólogos do século XX, com peças que marcaram profundamente a história do teatro, entre elas: $\mathrm{Na}$ selva das cidades, A exceção e a regra, Mãe Coragem, O círculo de giz caucasiano, Galileu Galilei.

Por volta de 1924, o jovem Brecht mudou-se para Berlim, onde começaria profícua carreira teatral, inicialmente como assistente de dois dos mais celebrados diretores da época, Max Reinhardt e Erwin Piscator. Estando vinculado às idéias de esquerda, Brecht chocou-se com a trajetória ascendente do nazismo, tendo que se exilar em países como França, Dinamarca, Finlândia e Estados Unidos - onde permaneceu entre 1941 e 1947. Acusado de atividades antiamericanas, retornou à Alemanha, fixando-se definitivamente em Berlim Oriental, onde fundou o Berliner Ensemble, grupo que promoveria significativas experiências com a linguagem teatral e que levou à cena as últimas peças escritas por Brecht.

Ocupado em dar continuidade à idéia de que só há conteúdo revolucionário se existir forma revolucionária e vice-versa, ele desenvolveu a teoria do teatro épico-dialético, que se opunha de maneira frontal ao teatro dramático, de fundo aristotélico, considerado pelo autor de Galileu Galilei como um mecanismo dramatúrgico que gerava ilusão da realidade, reduzindo, em conseqüência, a capacidade crítica do espectador. A teoria brechtiana propunha o chamado efeito de distanciamento, através do qual caberia evidenciar os processos cenográficos,

1. COMUNICAÇÃO \& Educação. São Paulo: CCA/ECA/USP/Paulinas, n. 3, ano $\mathrm{XI}$, set./dez. 2006; Ibid. 2007. 
mostrando as estratégias que envolvem os diversos elementos que entram na economia geral da peça; com isso, o objetivo era de ao mesmo tempo quebrar a ilusão do real e intensificar a percepção crítica do espectador, colocando-o diante dos desafios ideológicos e políticos propugnados pelo texto teatral.

A poesia escrita por Brecht não alcançou a dimensão de grandiosidade das peças teatrais; contudo, ela também possui importância pelo caráter antisentimental, combativo e mesmo didático. Tanto nos textos que compõem O livro da devoção caseira (Die Haupostille), de 1927, quanto em Poesias de Svendborg (Svendborger Gedilchte), de 1939, é perceptível a mesma preocupação com o efeito de estranhamento, traduzida em poemas de alto envolvimento político, desdobrado em temas como a resistência à barbárie, a luta pela justiça social, a denúncia da alienação e o engajamento em acontecimentos sociais. Em uma palavra, segundo a compreensão de Brecht, poesia e revolução social devem caminhar do mesmo lado.

\section{POEMAS DE BERTOLD BRECHT}

\section{Os que lutam ${ }^{2}$}

Há aqueles que lutam um dia; e por isso são muito bons;

Há aqueles que lutam muitos dias; e por isso são muito bons;

Há aqueles que lutam anos; e são melhores ainda;

Porém há aqueles que lutam toda a vida; esses são os imprescindíveis.

\section{O analfabeto político ${ }^{3}$}

O pior analfabeto é o analfabeto político.

Ele não ouve, não fala, nem participa dos acontecimentos políticos.

Ele não sabe que o custo de vida, o preço do feijão,

do peixe, da farinha, do aluguel, do sapato e do remédio

dependem das decisões políticas.

O analfabeto político é tão burro que se orgulha

e estufa o peito dizendo que odeia a política.

Não sabe o imbecil que da sua ignorância política nasce a prostituta,

o menor abandonado, e o pior de todos os bandidos que é o político vigarista,

pilantra, o corrupto e lacaio dos exploradores do povo.

2. <http://www.comunismo.com.br/brecht.html>. 


\section{Privatizado ${ }^{4}$}

Privatizaram sua vida, seu trabalho, sua hora de amar

e seu direito de pensar

É da empresa o seu passo em frente,

seu pão e seu salário.

E agora não contentes querem

privatizar o conhecimento, a sabedoria,

o pensamento, que só à humanidade pertence.

\section{Perguntas de um trabalhador que lêt}

Quem construiu a Tebas de sete portas?

Nos livros estão nomes de reis.

Arrastaram eles os blocos de pedra?

E a Babilônia várias vezes destruída -

Quem a reconstruiu tantas vezes?

Em que casas da Lima dourada moravam os construtores?

Para onde foram os pedreiros,

na noite em que a Muralha da China ficou pronta?

A grande Roma está cheia de arcos do triunfo.

Quem os ergueu? Sobre quem triunfaram os Césares?

A decantada Bizâncio tinha somente palácios para os seus habitantes?

Mesmo na lendária Atlântida,

os que se afogavam gritaram por seus escravos,

na noite em que o mar a tragou.

O jovem Alexandre conquistou a Índia.

Sozinho?

César bateu os gauleses.

Não levava sequer um cozinheiro?

Filipe da Espanha chorou, quando sua Armada naufragou.

Ninguém mais chorou?

Frederico II venceu a Guerra dos Sete Anos.

Quem venceu além dele?

Cada página uma vitória.

Quem cozinhava o banquete?

A cada dez anos um grande homem.

Quem pagava a conta?

Tantas histórias.

Tantas questões.

4. Ibid.

5. BRECHT, Bertolt. Poemas: 1913-1956. São Paulo: Brasiliense, 1986. Seleção, trad. e posfácio: Paulo Cesar Souza. 
comunicação \& educação • Ano XII • Número 2 • maio/ago 2007

\section{Um homem pessimista ${ }^{6}$}

Um homem pessimista

É tolerante.

Ele sabe deixar a fina cortesia desmanchar-se na língua

Quando um homem não espanca uma mulher

E o sacrifício de uma mulher que prepara café

para seu amado

Com pernas brancas sob a camisa -

Isto o comove.

Os remorsos de um homem que

Vendeu o amigo

Abalam-no, a ele que conhece a frieza do mundo

E como é sábio

Falar alto e convencido

No meio da noite.

Como se percebe deste conjunto de poemas, eleva-se a temática social, política, de chamamento à consciência e à participação dos cidadãos. Podemos dizer que se cria um ambiente discursivo preocupado com a comunicação com os leitores e que recolhe e expande diálogos com outros textos de poetas nutridos pelas temáticas evidenciadas por Brecht. É neste quadro de contaminações interdiscursivas que filiamos Eduardo Alves da Costa, Martin Niemöller e Bertold Brecht. 